\title{
A Journey from Peking to Tsitsihar
}

\section{Author(s): Claud Russell}

Source: The Geographical Journal, Vol. 23, No. 5 (May, 1904), pp. 613-623

Published by: geographicalj

Stable URL: http://www.jstor.org/stable/1776007

Accessed: 27-06-2016 06:24 UTC

\section{Your use of the JSTOR archive indicates your acceptance of the Terms \& Conditions of Use, available at}

http://about.jstor.org/terms

JSTOR is a not-for-profit service that helps scholars, researchers, and students discover, use, and build upon a wide range of content in a trusted digital archive. We use information technology and tools to increase productivity and facilitate new forms of scholarship. For more information about JSTOR, please contact support@jstor.org.

The Royal Geographical Society (with the Institute of British Geographers), Wiley are collaborating with JSTOR to digitize, preserve and extend access to The Geographical Journal 
descendants of Portuguese and Spaniards, and promises to break down many of the prejudices which they unhappily took with them to the New World.

\section{A JOURNEY FROM PEKING TO TSITSIHAR.*}

By CLAUD RUSSELL, M.A.

ThE route followed by Mr. Hicks Beach and myself was roughly a north-easterly one from Peking to Tsitsihar. It was suggested by Lieut.-Colonel Wingate, in charge of the Intelligence Branch of the British Forces in North China, as likely to afford new ground. We were accompanied by a Chinese servant, a cook, and two pony-boys, who all worked well and gave no trouble. We reached our destination on our forty-ninth day from Peking, the distance covered being a little over 1000 miles.

The road from Peking to Jehol has been described by Sir Geo. Staunton in his record of the first English mission to China. It has not changed since Lord Macartney passed over it in his gilt coach 110 years ago. It only strikes one that the dilapidation and decay, which now mark so much of China, were not then such as to excite the comments of the traveller. Jehol itself has been many times visited since then. The "Versailles of China," as the Abbé Huc calls it, is a squalid and uninteresting town. It has ceased to be a royal residence in this generation, but as the seat of government of the northern "March" it retains its official importance. The wall of the imperial park is the most prominent feature of the town. No European has entered it since Lord Macartney was received by the Emperor Chienlung, and the account of the author above mentioned is, as far as I know, the only foreign description we have of it. There appears to be no one prominent building, but a number of kiosks and pavilions are scattered over the park and on the slopes and summits of the hills enclosed in it. Such as are near enough to the wall for a view to be had of them are approaching a ruinous condition. There are streams and lakes in the park, and the grass is of a colour rare in Northern China. These, with the deer feeding under the trees, present a singularly charming aspect when seen from without on a hot day. No emperor has visited Jehol since Hsien-feng, the husband of the present empress dowager, died there on August 22, 1861. But though the family has been so long absent, their wardrobe awaits them. The annual airing took place while we were in Jehol. The high officials of the Government repaired to the palace and stood round for the space of three hours while the imperial silks and sables were exposed to

* Map, p. 704.

No. V.-MAY, 1904. 
the sun. The temples of Jehol are in a sad state of decay. This is especially the case with the two lama monasteries. They retain nothing of the magnificence ascribed to them in Staunton's description. They are unique among buildings in China. Both are square, or rather cubic, blocks over 150 feet high. The variegated colours of the eleven stories are all but washed out. On the altars of the temples inside are priceless bronzes, porcelain, and cloisonné, all inches deep in dust. We noticed particularly some French eighteenth-century vases on which were depicted scenes from life in châteaux of the period, very unsuitable for altar decoration. Beyond that they were "foreign," the lamas knew nothing of their origin. These buildings are modelled on the residences of the Dalai Lama at Lhasa, and of his subordinate at Shigatse, and the former is likewise known in Jehol as "Potala." Those who have seen both say that it is a perfect counterpart, though on a smaller scale. The local explanation is that the emperor was anxious that the grand lama should feel at home while in attendance on the court during its annual three months' stay at Jehol. Taking into consideration the time occupied by a yearly journey to Lhasa and back, one is led to the conclusion that the time left him to attend to affairs in his own capital must have been very limited. However this may be, an inscription in the building dedicates it to the memory of three remarkable events which took place during its construction, namely, the desertion of the Kalmuk Tartars of Russia and their return to Chinese allegiance, the sixtieth birthday of the emperor, and the eightieth of his mother. When we read that these achievements were crowded into a space of two years, and consider that the reign of Chien-lung extended over sixty years, we cease to wonder that the period is reckoned glorious in Chinese history.

The local officials of Jehol, though most obliging, were not encouraging as to our being able to follow the route we wished. It lay across the Wei Chang, the hunting-ground of the emperors. We were assured that this was uncrossable; that it was in part an impenetrable jungle, in part a desert; that it was inhabited by tigers and bears; that it was at that moment the refuge of a brigand chief; and, finally, that our way would lead us through a distressed district in which it would be unwise to expose the population to the temptation of our stores. I may here say that, as far as our acquaintance with the Wei Ch'ang went, it is crossed by good cart-tracks, that the greater part of it is cultivated and inhabited, and that it contains nothing more dangerous than pheasants.

We had some difficulty in obtaining mules with which to continue our journey beyond Jehol. This was in part due to the impossibility of making known the time for which we might require them, or where we wished to go. The name Tsitsihar appears to be unknown to others than Europeans. The Mongol name is Bukwéi. The Chinese 
official name being Hei-lung-chiang, I am at a loss to explain the derivation of "Tsitsihar." The five mules and a donkey we finally engaged constituted our transport for the next thirty-three days. The mule of China is an animal of great endurance. I believe the maximum load for a mule is reckoned in the army at $130 \mathrm{lbs}$. I had no means of reckoning what one of ours carried beyond that it took six men all their strength to hoist the pack on to its back. The saddle on which this rested cannot have weighed less than $20 \mathrm{lbs}$. With this load it would walk 30 miles a day. The latter part of the journey they did entirely on grass, a food to which they must have been wholly unaccustomed. These mules are not the magnificent animals which are to be seen in Peking. They are lean and scraggy, and stand little uver 14 hands.

The stony valleys and empty watercourses which characterize the country between the Great Wall and Jehol are continued for another 80 miles beyond that place. We went through the town marked on maps as Po-ro-ho-tun, but locally known by its Chinese name of Huang-ku-t'un. It is a fair-sized place with a busy market, and lies in a small fertile valley surrounded by hills. The country population of this disirict is scanty, but apparently not over-poor. The ordinary grains are grown, and some rice, but the staple crop is the poppy. There is no novel without its adjoining patch. The opium harvest was in process of being gathered. I noticed that the heads were sliced horizontally, and not as I have seen it done elsewhere. It would appear that this must be added to the number of little facts which are cited to illustrate the contradictoriness of the Chinese nature. The impression at leaving the cultivated country and entering the first wild valley of the imperial hunting-grounds is one of indescribable charm. Through it runs the I-sun Ho, a deep and rapid stream of clear water. The hills are low and well wooded, and the grass is long and full of flowers. The novelty of such surroundings to any one coming from the plain of Peking adds to its delights. Unfortunately, its does not last long. Maps and popular report had led us to believe that the Wei Chang (as such) extended north for a distance of 100 miles. We had not gone 10 before we came again upon signs of human habitation. Why this apparent belt of wild country has been preserved, I cannot say, unless it be on the principle which is known to Europeans in China as "look see." The encroachments on the imperial preserves are evidently in this part of recent date. The inhabitants had all the appearances of pioneers; their cultivation is patchy, and they are living in log-huts, owning nothing apparently but a plough and a yoke of oxen. There are no women. I believe this work is in process throughout the Wei Chang, of which, no doubt, there will soon be nothing left to tell its former character. In the more northern portions which we crossed, the work is long accomplished. 
There there are small villages and well-built farmhouses which cannot date from less than a hundred years back. Of special Government supervision over this territory or of imperial gamekeepers, of which other travellers have spoken, we saw or heard nothing. Huc, writing in 1844, says that it was then twenty-seven years since the emperor had hunted there. Venery has ceased to appeal to the decadent character of the last Manchu emperors, and the forest has lost its raison d'etre. Of game, other than birds, we saw nothing beyond a herd of Huangyang (Antilope gutturosa), and an animal the Chinese name of which is exactly represented by the English sound "lady." This, though not the Chinese for a wolf, appears, to judge by the animal we saw, to be a local name for it.

On many maps the Khingan mountains may be seen marked as a well-defined chain running north and south. The country through which we travelled was, from within 60 miles of Peking and 30 of Tsitsihar, a continuous mountainous tableland, varying between 2000 and 3000 and even 6000 feet; nor was any predominating range at any time visible. As to the existence of Mount Petcha, which one may see set down as a peak among the Khingans, with a height of 10,000 feet ascribed to it, we were led to entertain doubts. The authorities for its presence appear to be the Jesuit Fathers Verbiest and Gerbillon, who travelled extensively in this country at the end of the seventeenth century. The latter, on Chinese authority, gives it a height of $9 l i$ (say 15,000 feet*), but describes it, not as a peak, but as " un amas de plusieures montagnes." He says that ice is to be found on it throughout the year, and hazards the suggestion that this is attributable to its great altitude. I am told that Dr. Bushell, in a record of a journey made in 1872, and which appeared in the Journal $\dagger$ of this Society, but which I have not seen, states that even the name of the mountain is unknown; and this was likewise the experience of the Russian traveller, Fritsche. Ours was similar, until a passer-by of exceptional intelligence suggested that it was perhaps "Paich'a" we were seeking. Inquiries after this name continued to meet with a response, but we could never connect it with mountains. It appeared to be rather applicable to a district, and two peasants, at whose farms we put up, claimed it as the name of their homesteads. As against this, Dr. Franke, in his learned work on the Jehol prefecture, states that when travelling in 1896 he located the mountains in question, known exactly by the name transliterated by the fathers, and that he made their greatest altitude roughly 10,000 feet. $\mathrm{He}$ admits their invisibility, which he accounts for geologically, and which is certainly remarkable, for in what must be the near neighbour-

* Or it is possible this height was computed on the Chinese system, i.e. that it was a walk of $9 l i$ ( 3 miles) from the foot to the summit of the mountain. Reckoned by our methods, this might reduce it to something very moderate.

$\dagger$ Journal, vol. xliv., 1874, p. 73. 
hood of the district indicated by him the road goes over a pass of 5100 feet; here, among the great extent of hills visible, there was certainly no point with an appearance of being more than 500 feet higher than we were. Dr. Franke identifies it with the range and plateau described by Huc as the "Sain Oula." But the Abbé's description of this country must strike those who have visited it as somewhat imaginative, even if he had not, a few pages previously, shaken his reader's confidence by recording a fall of hailstones weighing 12 lbs. each.*

On our seventh day after entering the Wei Ch'ang, following the course of Ta-chi-ku, a small stream, we crossed what we took to be the Shara Muren. There was no one near from whom to ascertain its local name. The track led from here through a sandy valley, with very scant vegetation in about 10 miles, to Ch'ing-p'eng. It is a busy Chinese town of mud houses, with perhaps 5000 inhabitants, prettily situated among the hills at a confluence of streams. It was visited, I believe, by Dr. Donaldson Smith in 1897, and, from the curiosity excited by our arrival, I should think by no European since then. $\dagger$ A comparison of the inhabitants with the unobtrusive peasants we had lately been among exemplified the bad effect of town life on manners, especially in the case of little boys. Provisions were obtainable here, and we laid in a store of flour, rice, and potatoes. There is no market between this and Tsitsihar. Here, also, through an obliging mandarin, we secured the services of a Chinese-speaking Mongol. His ignorance of the country prevented his being much use as a guide, especially as his conception of guiding was to ride 10 miles ahead of the caravan, on the pretext of preparing the matives for our arrival, but really iecause he thus shortened his day's march by some weary hours. He was indispensable, however, as an interpreter, and his introduction of us to his compatriots always produced a warm welcome. He had a useful capacity for borrowing horses, and be never failed to secure two or three. These horses would often make a stage of several days with us, and, on arrival at a settlement, others would take their place. By what means they found their way back to their owners I could never make out, but the arrangement seemed to bo an accepted custom of the country.

For nearly two days beyond Ching-peng there is no change in the character of the country. There is the same tedious succession of fields and valleys. With the exception of the poppy-crop, the cultivation is

* Since writing the above, I have seen a reference to Mount Pecha in a memorandum of a journey by Mollendorf in this district in the Society's Journal of February 1881. He says the Chinese inhabitants speak of a mountain called "Baitcha," and that reference to it may be found in Chinese literature. He does not appear to have visited it, and gives its situation and height (9000 to 10,000 feet) on Chinese authority. The mystery of this veritable "Mont Perdu" seems still to call for elucidation.

+ 'The boots at the inn told me, with much laughter, that the town was also known as "Ch'ingli-ch'ing," or "P'engli-p'eng." No doubt a local joke of great antiquity, which I forbear to translate. 
very poor. New farms and houses in course of building mark the recent advent of the Chinese. Their present limit is about 35 miles north of Ching-peng, at the village of Lu-chia-ying-tsu. I note the name, in the hope that subsequent travellers may mark the rate of advance. The change is clearly marked. There is no half-and-half country. As one leaves the village, cultivation ceases, and the grass country begins. The Chinese are showing the capacity, of which they have given evidence in many parts of the world, for ousting the original inhabitants. The present extent of Chinese colonization outside the Great Wall is probably a growth of not more than the last 100 years. There seems no reason why it should not continue in the direction it is following (given a growing population) until these settlers join hands with their countrymen of Northern Manchuria, from whom they are undistinguishable in all apparent characteristics. The grass country is not one that at first sight seems suited to colonization. It is destitute of wood, and water is often scarce. It must be remembered, however, that the Chinese peasant is not dependent on the former. He grows his fuel with his crops, and with millet stalks and straw he has a sufficiency for his winter firing. The "argol " fuel of the present pastoral inhabitants would be no longer procurable with the disappearance of their herds. As regards water, I believe that, though one may often do a day's journey without seeing any, it could in many places be found by digging. In any case, there are now many miles of broad well-watered valley entirely uninhabited.

There are some hot springs by the road about 20 miles north of Ching-peng. The place is named Tang-shan. The arrangements for those anxious to benefit by their healing properties are very primitive. A row of twenty or thirty wooden boxes, the size of an ordinary packing case, are ranged beside the road. In these sit bathers of every age and both sexes, with their heads protruding. Attendants with buckets continuously refill the boxes from the springs. For less luxurious bathers, there is accommodation in a pool which has been dug out close by. In this they squat, scooping up the water and pouring it over their heads with brass basins. It is curious to reflect that establishments like Homburg and Aix-les-bains have had their origin in such beginnings.

The maps of this country which I have seen are of little use to the traveller. The names on them appear to be the product of fancy. I believe the most recent, and certainly the most detailed, is one published in 1900 by the Russian Department of Finance. I failed to identify a single name on this map north of Ching-peng. Making every allowance for changes consequent on Russian transliteration and re-transliteration into English, it is difficult to conceive from what source they were derived, unless it is that they mark Mongol camps, noted by some traveller, which now no longer exist. We were at first, not unnaturally, led to believe that they indicated the sites of populous towns, and having fixed on one which appeared to be on our line of route, we 
ordered our guide to take us there. Anxious for his reputation, he acquiesced, and, after leading us in varying directions for two days, finally halted in a barren valley, and announced that this was undoubtedly the spot we were seeking. After this, until we were within a few days of Tsitsihar, when it became possible to go by native directions, we took our course from the compass. In all matters connected with the road, distances, direction, the presence of inhabitants or water, etc., we always found the natives, I believe with the best intentions, the most consummate liars. About 50 miles off Ching-peng the Russian map above mentioned marks " Tomb of the Chinese Empress." We found a tomb approximately on the spot, but it is difficult to see how this description became attached to it. It is a seven-storied pagoda, and the only building of any pretensions in all the country we passed through. A Peking Chinese, a Government guardian in charge of it, told us it was 2000 years old, and the resting-place of a Mongol lama, and that it was called the "White Tower." He said that the right road to it from Peking was through Lama Miao, and that we were assuredly the first Europeans who had been there. As, however, I see an unmistakable photograph of the tower (but without any letterpress) in Dr. Franke's book, before mentioned, I fear we cannot claim this distinction. The designs on its face are un-Chinese in character, and one especially depicts a very Assyrian bull (or lion). Round the base of the tower attendant lamas walk unceasingly, carrying each, on a wooden pack upon his back, a load of books. I have never seen this form of devotion elsewhere. The altar decoration of the shrine within is a silver teapot with three peacock's feathers in it. Lamaseries, of which we came across four or five, are the only buildings in this country. They are wretched conglomerations of mud houses surrounding three sides of a temple. Contrary to what is usually reported of them, we always found the lamas civil and friendly. The settlements of the lay inhabitants are the same "yourts" as those of the Western Mongols, i.e. tent-shaped huts of wattle and felt. It is curious that men who are so rich in some respects-in cattle and sheep or ponies-should be satisfied to live in such discomfort. Their personal dirt is beyond description. They are a cheerful people, with a great idea of their obligations towards the stranger, and, at the same time, without any great curiosity in him. They have none of the demeanour, so offensive in the Chinese, which the Rev. A. Smith describes as " amused interest combined with depreciation." If they allow themselves to stare, it is with honest admiration for all one's belongings. Unlike the Chinese, they have none of their preconceived ideas of the unpleasant peculiarities of foreigners, which make us so interesting to them. The Chinese regard them as very poor creatures, and adopt towards them the manners of a dominant race; nor did I ever see it resented. Their most striking peculiarity is their indifference to money, for which they seem literally to have no use. 
They place all they have at the disposal of the stranger, but no payment is expected. It is possible to live well on the food of the country, as far as it goes. The milk and cream are of the best. On arrival in camp, a sheep is killed for the stranger's benefit.* It is worth going to Mongolia to eat mutton, which is unlike any other in my experience. No trareller who has written on the country fails to mention it. Missionaries, Protestant and Catholic, alike refer to its succulence. There is also a very excellent product of milk to be had, peculiar to the country. It is made in large round flexible flaps, about a quarter of an inch thick, with a hard coating top and bottom, and a substance resembling Devonshire cream in between. I was unable to find out by what process it is made. Colonel Younghusband mentions it, and refers to the value its portability gives it for the traveller. Though there is much cattle in the country, beef is never seen. Oxen are kept and driven to the Chinese markets in the winter, where they are exchanged for grain and such small requirements as their owners have. It is said that drunkenness is a national failing of the Mongol. I have never seen soberer people than those we met. Only on one occasion, when a jar of Chinese wine was produced as a matter of ceremony, were we offered alcohol in any form, and we were never asked for it. Tea, with an admixture of salt and mutton grease, is the common beverage. It is not recommendable. Snuff-taking is universal, and the offer of the snuff-bottle is the general method of greeting. These Mongols appear to seclude their women in some measure, at least from strangers, and our arrival was usually the signal for a hasty departure of the ladies of the family for the tents of their next neighbours. Children are scarce, and the impression left is one of a diminishing population.

A Mongol prince has his seat at Chastuchi. The situation is a very pretty one, in a broad grassy valley which, unlike any other, is well planted with trees. An embattled wall of mud surrounds the settlement, and encloses a considerable space. Outside the gates are the great poles emblematic of official China. The inside is further divided by walls, and contains many separate houses, some in Mongol and some in Chinese style. We were most hospitably received, and assigned a clean and roomy "yurt," comfortably fitted with Chinese furniture. The prince's visiting-card, written in parallel columns of Mongol and Chinese, describes him as Chieftain of the Horchin Tribe of the Cherim League. $\dagger$ It also states him to be the holder of an appointment

* Their method of killing sheep is curious and unpleasant. The animal is thrown on its back, when the butcher makes an incision in its belly, into which he thrusts his hand, where he presumably severs an artery, as death ensues and the carcase is suffused with blood. He then takes a ladle and transfers the blood to a receptacle at his side. No drop is spilt.

† His attendants refused to tell us his personal name; nor would he, when asked, say it before them. I imagine it was only a form of deference, for which parallels exist with us, and not a case of taboo. 
connected with one of the gates of the imperial palace in Peking, whither his duties call him once in three years. He is a man of unmistakable breeding, of the good-looking type, with a very white complexion. He wears Chinese official dress, with a button of the Prince of the Blood. $\mathrm{He}$ is treated with marked respect by his dependents, and the general air of the place left on one an impression of happy patriarchal life and simplicity. He knew no language but Mongol. He had plenty of conversation, and asked many questions about his guest's country, whether we lived in tents, and owned cattle like he, etc., and whether in our travels we had not visited Lhasa. Politics do not seem to trouble him, and he did not know whether or not Tsitsihar (distant five days) was still in the occupation of a foreign army, although he had heard of its being so. He was more interested in shooting, which he practises from pony-back, and uses a modern breech-loader. When we left, he supplied us with a cart and a mixed mule and pony team for our luggage, which very much expedited our progress, as we were able to dismiss our packmules. I would recommend travellers in this country to rely on cart transport. There is no reason why one should not drive anywhere in a comfortable victoria. It is crossed in every direction by well-marked tracks through the grass, and in some places, where these are well worn, there is all the hardness and appearance of a metalled road. We met no cart traffic, but to account for the condition of the roads, there must be a good deal at some period of the year. The country beyond Chastechu, following the valley of the Gadlin river, is fairly well wooded, and comparatively populous. Here one begins to see traces of settled habitations. Some houses, though retaining the tent form, are solidly built of mud, but one also sees them of Chinese type. There is some cultivation round the houses, and the inhabitants make hay, keep poultry and pigs, ride donkeys, and sometimes even walk, contrary to the Mongol habit of never stirring without a pony. As one approaches the Manchurian border, one finds Mongol farms and villages, of which the inhabitants, except as regards their language, are not distinguishable from Chinese. It is not easy to see why they should have come so strongly under Chinese influences, when the Mongols of the southern border, though, one would think, in closer contact with them, retain their national habits unaffected.

The rivers we crossed contain little water. They follow courses of extraordinary tortuousness. The Gadlin and Yala Ho are of a fair size, and might be navigated ky boat, but the Shaling Golla was the only one we crossed which was not fordable on horseback.* Small streams and torrents, such as are usually associated with a hilly country, there are practically none.

* The owner of the dug-out boat, who ferried us across, is remembered by me as the only Mongol we met who asked for money. 
The summer climate is very temperate. The minimum night temperature varies between $40^{\circ}$ and $50^{\circ}$. It fell to freezing-point on one occasion (end of August), the altitude being 2100 feet. Although the season was that known as "rainy" in North China, rain did not fall on more than half a dozen days, and then in moderation.

The country cannot be called rich in animal life. Snipes are plentiful along the rivers, and so are plovers, and during the latter part of the time we found an abundance of quails. There is also a large grey goose, of which we were unable to obtain a specimen, and a smaller one with a terra-cotta back and parti-coloured black-and-white wings, which I have been unable to identify. A crane (Grus cinera) is common in couples. There is no large bird of prey. Unfortunately, Mr. Hicks Beach's collection of birdskins, being left one night outside the tent, fell a victim to a marauding dog, which also disposed of about $20 \mathrm{lbs}$. of flour. We only once saw deer (or antelope)-three hinds-some distance off, but inquiries of the natives with regard to them always led to assurances that if we had only been there the day before, or would wait a little, we would be satisfied. Of smaller mammals, two hares were shot (Lepus hispidus, I think). They were about the size of a small English rabbit. The burrows of an animal, presumably of the marmot tribe, are very common, but their inhabitants appear to be nocturnal. There is no lack of insect life in the long grass, both in numbers and variety. The general absence of mosquitoes is a boon to the traveller. We only came across them once, and in curious circumstances. We had camped in the dark without water, and there was none, so far as I know, for 15 miles on either side of us. Shortly after sunrise mosquitoes made their appearance. They attacked, not in the usual tentative manner, but with the ferocity of angry bees, and only let go their victims when killed. The Mongols with us suffered equally with ourselves. They pursued us in clouds for about 10 miles, and then left as suddenly as they had appeared. Except for their apparent independence of water and diurnal habits, they had the characteristics of others of their sort.

There is perfect security in the country we passed through. It might have been thought, from accounts of the great bodies of brigand cavalry with which the Russians have had to deal in their pacification of Manchuria, that some remnants of these might have been pushed over the border and be pursuing their occupation in Mongolia. But we saw nothing of them, and heard no stories of anything of the sort.

It has been indicated that this country, from its winter climate and absence of fuel, offers no field for European colonization. Also, that it is not a "sportsman's paradise." I sbould like to add that, unlike most little-visited districts, I see no reason for believing it to be "rich in undiscovered minerals." Further, that it appears to offer no prospects 
to railway enterprise. A line through it would hardly be described in the most sanguine prospectus as "tapping rich districts."

We struck the Manchurian railway at Fulardi, about 20 miles from Tsitsihar station. A vexatious corporal, in charge of a piquet by the Nonni river, made it clear to us that we had passed under the jurisdiction of another power. I may say that Western civilization, with its bayonets and jerry building, as seen at a Manchurian railway station, presents an unattractive aspect beside that of the free herdsmen we had been among. We returned to Peking from Tsitsihar by rail in five days.

Throughout the journey we met with the unfailing courtesy and consideration from all classes which is the experience of most travellers in China, and often in contrast to what may be met with in Europe among nations who lay claim to a higher civilization.

\section{ON THE DIMENSIONS OF DEEP-SEA WAVES, AND THEIR RELATION TO METEOROLOGICAL AND GEOGRAPHICAL CONDITIONS.}

By VAUGHAN CORNISH, D.Sc., F.G.S., F.C.S., F.R.G.S., M.J.S., Associate of the Owens College, Manchester.

\section{PART I.}

No really good method of measuring the height of waves from a ship on her course has yet been introduced into general use, but numerous rough measures of height have been made, based upon the principle that when a wave-crest, passing not far from the ship, just obscures the horizon, that crest has the same altitude as the observer's eye.

When an observer has made such estimates a daily practice he becomes fairly expert, and, according to the late Lieut. Paris, who was one of the most diligent of such observers, the estimate may be relied upon to 1 foot in 10 .

The measurement of the distance from crest to crest of two following waves may be carried out with some approach to accuracy if the co-operation of two observers be secured (who can simultaneously note the position of two succeeding crests along the ship's side), or with the aid of a buoy towed at a known distance astern.

In addition to the measurements of height and length, those of the velocity of the wave, and the interval of time between the passage of two crests, may be considered as two of the "dimensions" which have to be measured. The velocity is determined with tolerable ease by two observers provided with suitable watches, whenever the course of the ship is nearly the same as that of the waves, whether the waves follow or meet the ship. The speed of the ship being known, this is added to, or subtracted from, the apparent, in order to obtain the true, speed of the waves. When the course of the ship makes a small 


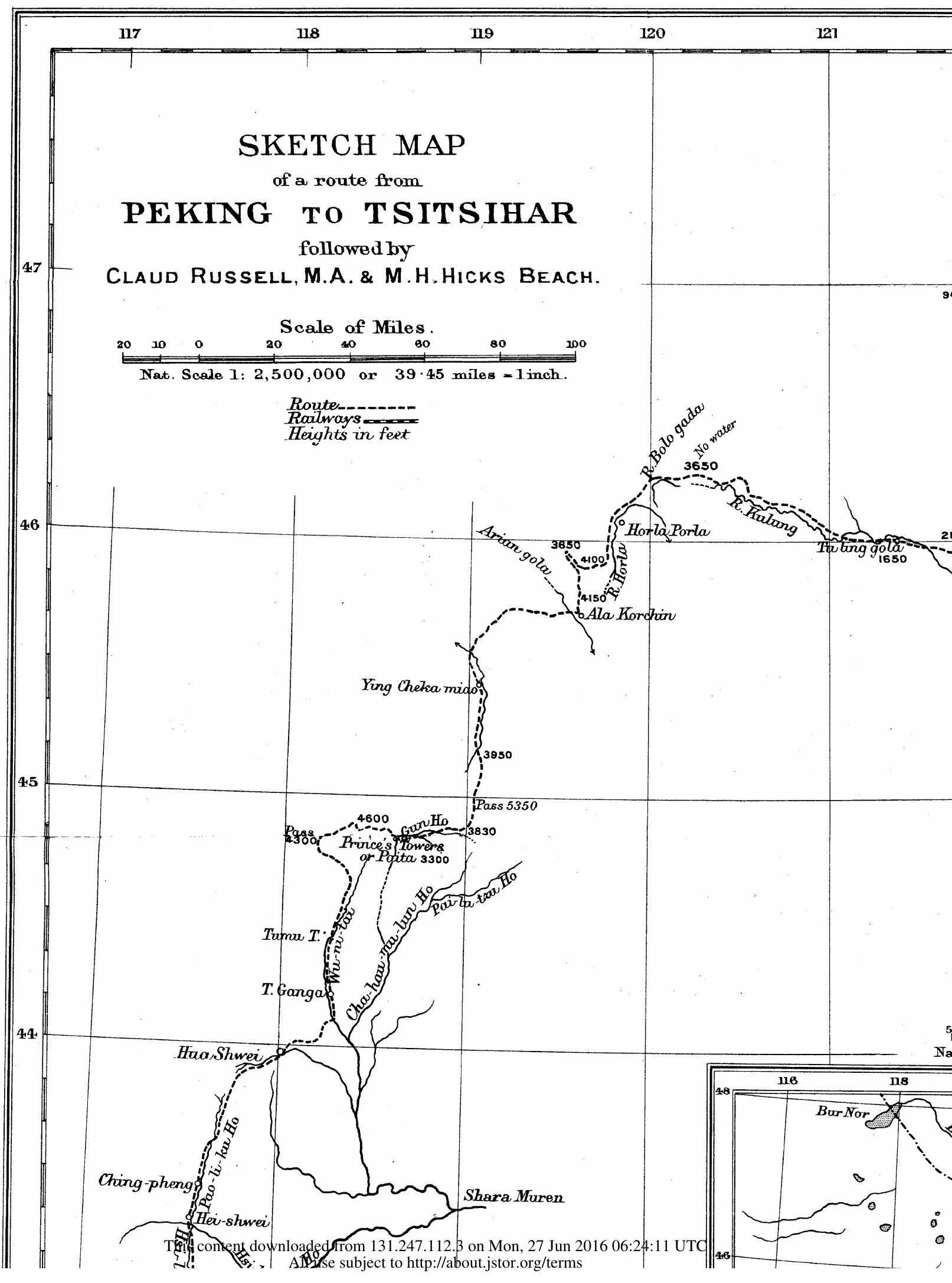


PEKING TO TSITSIHAR.

RUSSELL \& HICKS BEACH.

THE GEOGRAPHICAL JOURNAL, 1904.

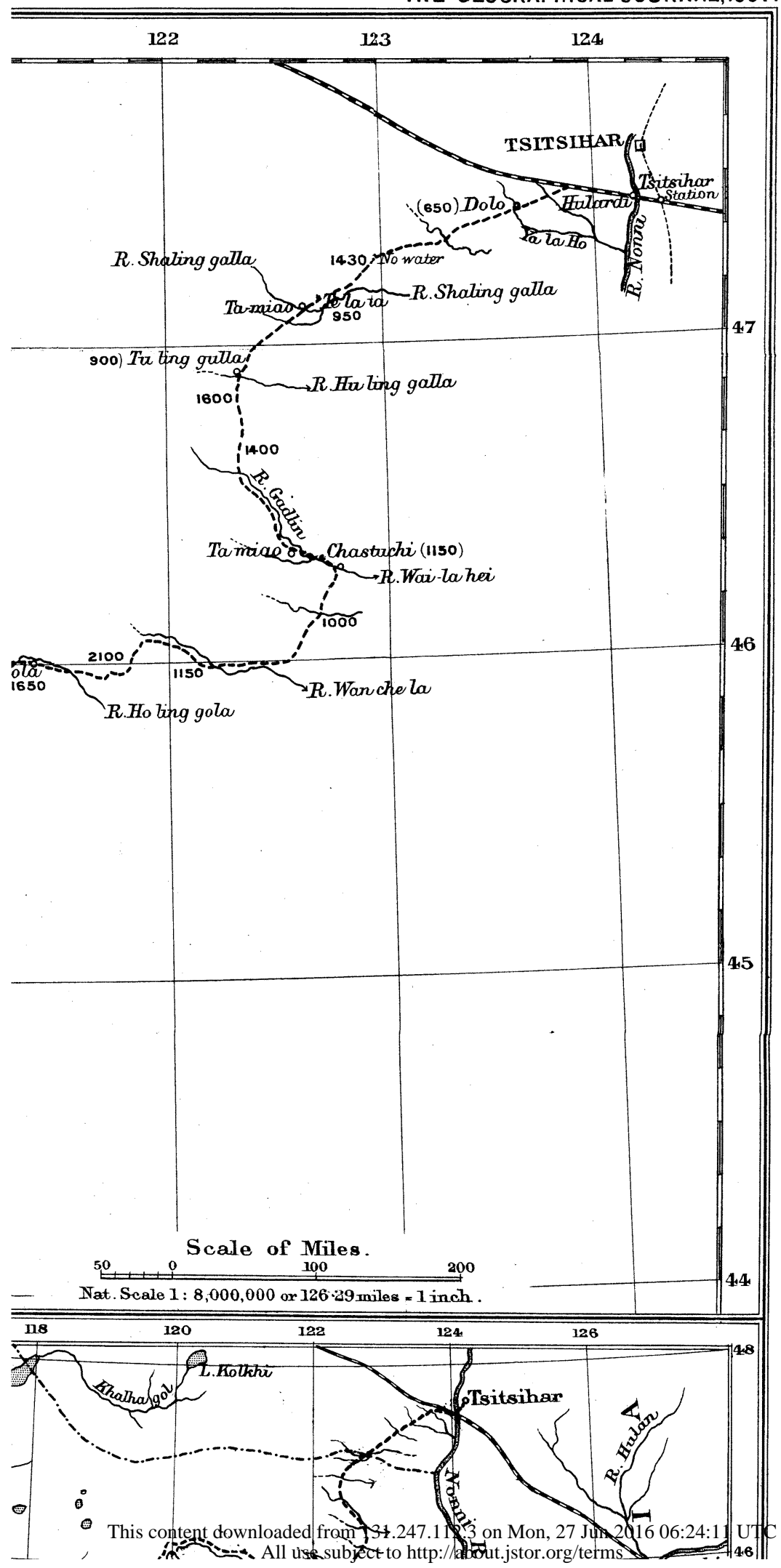




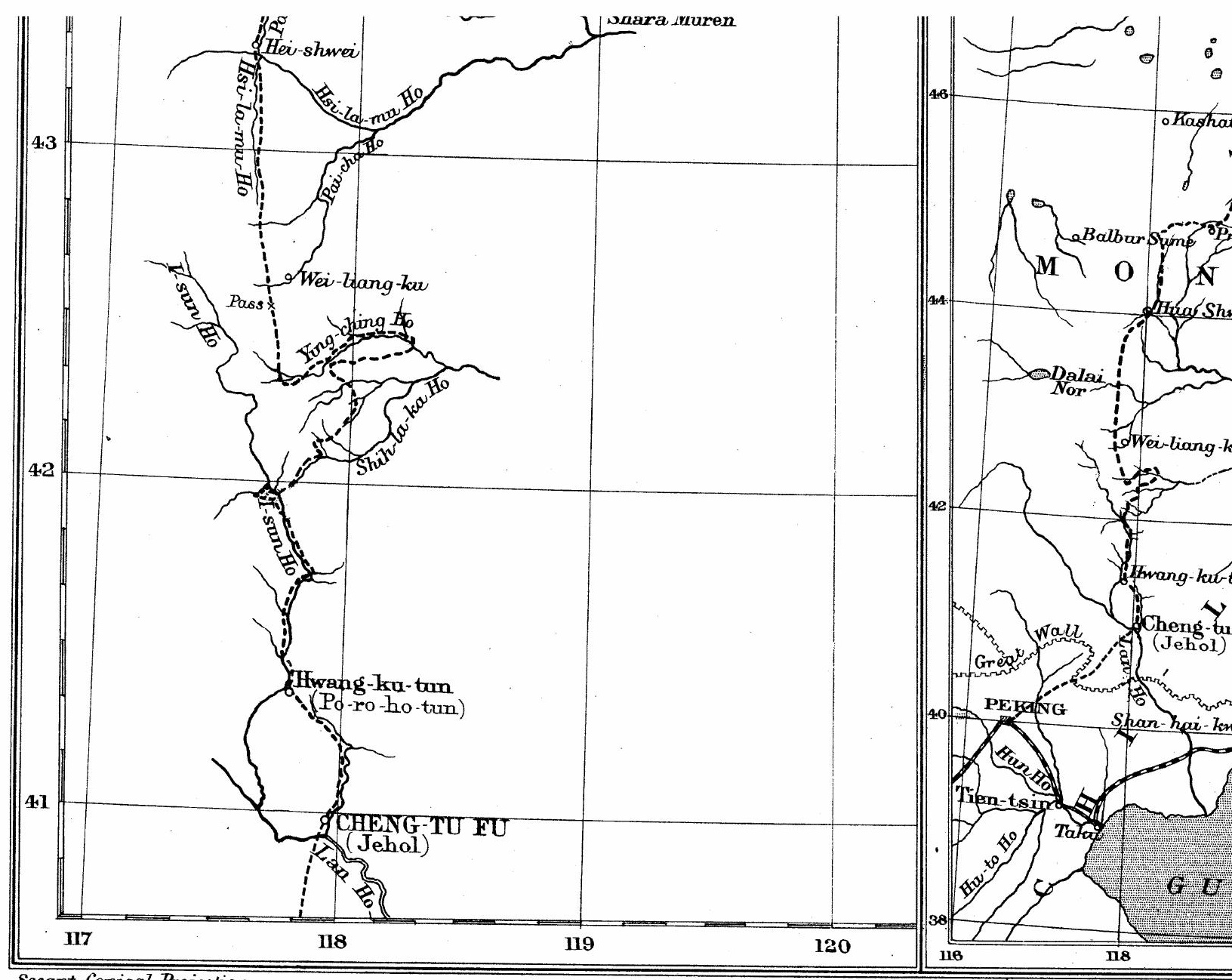

Pubtished by the Royal Geographical Society. 


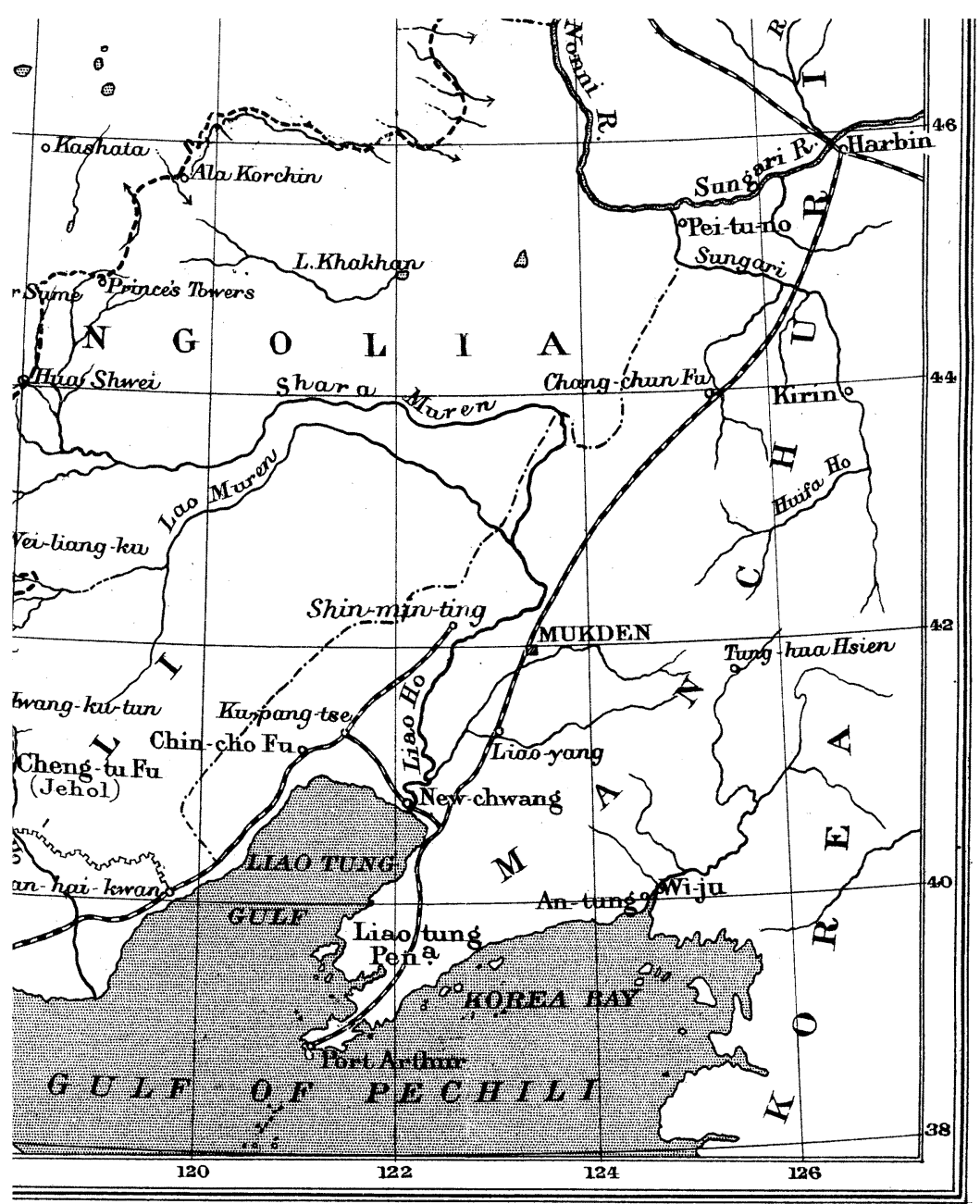

